\title{
Strategies for the identification and tracking of Cronobacter species: an opportunistic pathogen of concern to neonatal health
}

\author{
Qiongqiong Yan and Séamus Fanning * \\ UCD-Centre for Food Safety, WHO Collaborating Centre for Research, Reference and Training on Cronobacter, School of \\ Public Health, Physiotherapy and Population Science, University College Dublin, Dublin, Ireland
}

Cronobacter species are emerging opportunistic food-borne pathogens, which consists of seven species, including C. sakazakii, C. malonaticus, C. muytjensii, C. turicensis, C.

OPEN ACCESS

Edited by:

Janine Jason,

Jason and Jarvis Associates LLC,

USA

Reviewed by:

Ekawaty Lutfia Haksari,

Sardjito Hospital, Indonesia

Nurulhasanah Othman,

Universiti Sains Malaysia, Malaysia

*Correspondence:

Séamus Fanning,

UCD-Centre for Food Safety, School of Public Health, Physiotherapy and

Population Science, UCD-Centre for

Molecular Innovation and Drug

Discovery, University College Dublin,

Room S1.05, Belfield, Dublin 4,

Ireland

sfanning@ucd.ie

Specialty section: This article was submitted to Pediatric Infectious Diseases, a section of the journal Frontiers in Pediatrics

Received: 28 January 2015 Accepted: 15 April 2015

Published: 05 May 2015

Citation:

Yan Q and Fanning S (2015) Strategies for the identification and tracking of Cronobacter species: an opportunistic pathogen of concern

to neonatal health.

Front. Pediatr. 3:38.

doi: 10.3389/fped.2015.00038 dublinensis, C. universalis, and C. condimenti. The organism can cause severe clinical infections, including necrotizing enterocolitis, septicemia, and meningitis, predominately among neonates $<4$ weeks of age. Cronobacter species can be isolated from various foods and their surrounding environments; however, powdered infant formula (PIF) is the most frequently implicated food source linked with Cronobacter infection. This review aims to provide a summary of laboratory-based strategies that can be used to identify and trace Cronobacter species. The identification of Cronobacter species using conventional culture method and immuno-based detection protocols were first presented. The molecular detection and identification at genus-, and species-level along with molecular-based serogroup approaches are also described, followed by the molecular sub-typing methods, in particular pulsed-field gel electrophoresis and multilocus sequence typing. Next generation sequence approaches, including whole genome sequencing, DNA microarray, and high-throughput whole-transcriptome sequencing, are also highlighted. Appropriate application of these strategies would contribute to reduce the risk of Cronobacter contamination in PIF and production environments, thereby improving food safety and protecting public health.

Keywords: Cronobacter species, molecular identification, whole genome sequencing, DNA microarray, highthroughput whole-transcriptome sequencing

\section{Introduction}

Cronobacter species (formerly known as Enterobacter sakazakii) are opportunistic pathogens of the family Enterobacteriaceae, which have been documented in life-threatening infections predominantly in neonates of $<4$ weeks of age (1). The mortality rate of Cronobacter infections ranges from 40 to $80 \%$, and includes the clinical syndromes of necrotizing enterocolitis (NEC), bacteremia, and meningitis $(2,3)$. This bacterium has been isolated from a range of food sources including dairy-based products, dried foods such as herbal tea, flour, nuts, adult and infant cereals, herbs and spices, dried meats, rice, and others (4-6). Additionally, Cronobacter species have also been cultured from a variety of different sources and environments based on surveillance studies, including from common house flies, households, livestock facilities, and food 
manufacturing operations, in particular powdered infant formula (PIF) production facilities (7-10). Contaminated PIF has been epidemiologically linked with many of the infections reported $(1,2)$. The capacity to detect and identify Cronobacter species, differentiating them from other members of the Enterobacteriaceae, would contribute positively toward a reduction in the health risks to vulnerable individuals. This review summarizes the laboratory-based approaches that can be used to detect, and trace this pathogen of importance to neonatal health.

\section{Conventional Culture Strategies}

The conventional culture method for the identification of Cronobacter species was first reported by Muytjens et al. (11). The International Organization for Standardization (ISO) and International Dairy Federation (IDF) published a technical standard protocol, known as ISO/TS 22964, for the detection of Cronobacter species from milk-based powdered formula. ${ }^{1}$ The US Food and Drug Administration (US-FDA) later established both a culture method for the detection/isolation of Cronobacter spp. and a real-time PCR method for rapid screening (12). The procedures and flowchart for the sample preparation, isolation, confirmation, and identification of Cronobacter species have been described in detail. ${ }^{2}$ Both ISO/TS 22964 and US-FDA method are currently accepted as reference methods for the identification of Cronobacter species.

\section{Immuno-Based Detection Protocols}

Efforts on immuno-based protocols have been made both commercially and within the laboratories. The enzyme-linked immunosorbent assay (ELISA) technology has been applied in the VITEK immuno diagnostic assay system (known as VIDAS, bioMérieux, France) for the detection of several organisms using kits, including Salmonella, Escherichia coli O157:H7, Listeria species, Campylobacter jejuni, and Staphylococcus species enterotoxins. The kits for Cronobacter species have been developed and early stage tests showed promising results (13).

\footnotetext{
${ }^{1}$ http://www.iso.org/iso/catalogue_detail.htm? csnumber $=41258$

${ }^{2}$ http://www.fda.gov/Food/FoodScienceResearch/LaboratoryMethods/ ucm289378.htm
}

Meanwhile, several antibody targets, such as IgG, IgY, and outer membrane protein A (OmpA), were used for the immuno detection of Cronobacter species (14-17). Hochel and Škvor (14) developed an indirect competitive enzyme immunoassay for the detection of Cronobacter species using polyclonal antibodies. The surface antigenic determinants in Cronobacter species using monoclonal antibodies (MAbs) and MALDI-TOF Mass spectrometry were also investigated (15). A sandwich ELISA was undertaken to detect C. muytjensii in PIF (16). Recently, two rapid analytical methods, including a pAb-based indirect ELISA and a sandwich ELISA using $\mathrm{pAb}$ and $\mathrm{mAb}$, were established for the detection of Cronobacter species in PIF (18).

\section{Molecular Detection and Identification}

Molecular detection techniques have always been regarded as useful tools to extend our understanding of the epidemiology of a bacterium of importance to human health. These protocols are usually designed to target unique genes contained on the genome of the pathogen of interest. For Cronobacter species, the molecular detection and identification targets are designed at various levels, including the genus-, species-, and serotype-levels, respectively as described in Figure 1.

\section{Genus Detection}

Cronobacter species were originally known as yellow-pigmented Enterobacter cloacae, being reclassified subsequently as Enterobacter sakazakii based on deoxyribonucleic acid (DNA)-DNA hybridization, biochemical reactions, pigment production, and antibiotic susceptibility (19). The phylogenetic relationships of Cronobacter species to that of other members of the Enterobacteriaceae were investigated for 126 isolates using partial $16 \mathrm{~S}$ ribosomal DNA (rDNA) and $h s p 60$ sequencing. These data identified four clusters within the genus and indicated substantial taxonomic heterogeneity (20). Further investigation using amplified fragment length polymorphism (f-AFLP) analysis, full-length 16S rDNA gene sequencing, DNA-DNA hybridization, in combination with phenotypic profiling, provided the grounds to consider the redesignation of E. sakazakii as a new bacterial genus. This was designated as Cronobacter species $(21,22)$.

A real-time PCR protocol, using a TaqMan-based design, was subsequently developed to aid in the detection of this genus. This method was originally described by Seo and Brackett (23). This

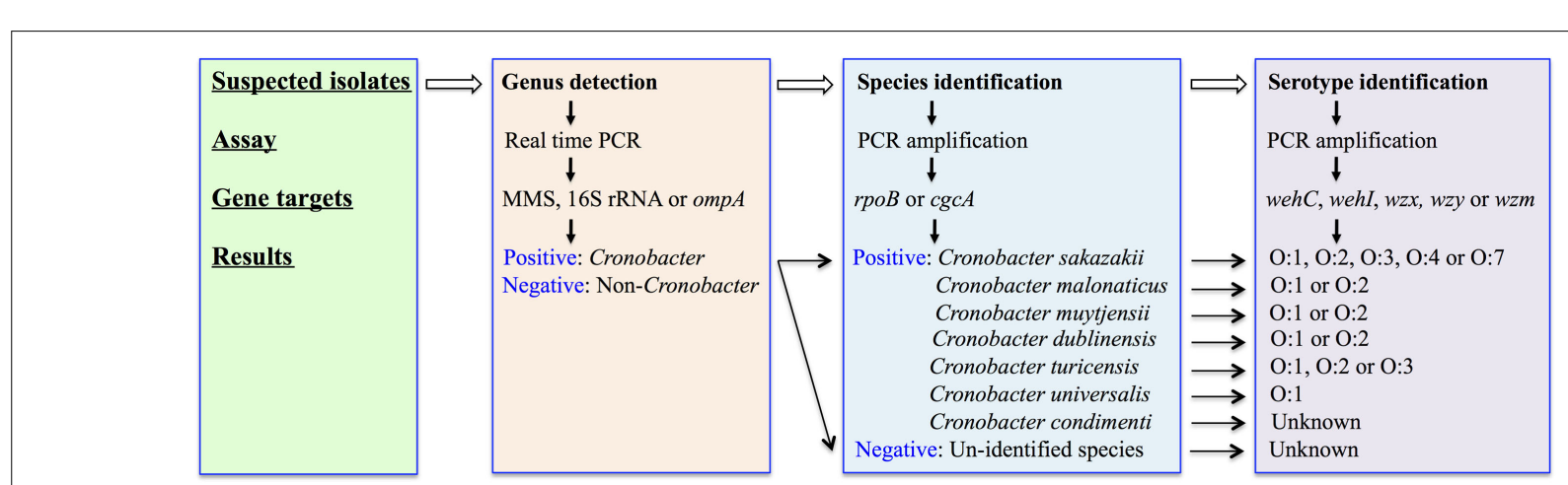

FIGURE 1 | A flowchart describes the molecular detection and identification of Cronobacter species at genus, species, and serotype levels 
approach focused on part of the macromolecular synthesis (MMS) operon (including the $d n a G$ gene at $5^{\prime}$ end and the $\operatorname{rps} U$ gene at $3^{\prime}$-end) to amplify a target sequence of $78 \mathrm{bp}$. Other strategies targeted different genes within the bacterium including 16S rRNA, ompA, and others (23-29). The 16S rRNA gene was later selected in a number of studies for the rapid detection of Cronobacter species using TaqMan $(24,27)$. Recently, the ompA gene has also been used as a target for the specific detection and rapid identification of Cronobacter species in PIF $(28,29)$. Both TaqMan and SYBR green assays were reported to be highly specific, sensitive, and efficient methods for the detection of Cronobacter species in infant formula-based matrices using suitable primers $(25,26)$.

Several commercial real-time PCR based protocols were made available, and which include the $\mathrm{BAX}^{\circledR}$ System PCR Assay E. sakazakii (DuPont, Qualicon, Wilmington, DE, USA), the Assurance GDSTM E. sakazakii (BioControl, Bellvue, CO, USA), and the foodproof ${ }^{\circledR}$ E. sakazakii Detection Kit (Biotecon Diagnostics, Potsdam, Germany) (30). In comparisons with the conventional ISO and US-FDA methods, these rapid detection systems reduce the time to detect Cronobacter species and therefore would facilitate a positive release strategy for finish products.

\section{Species Identification}

Originally six Cronobacter species were defined on the basis of $\mathrm{f}$ AFLP fingerprints, ribotype patterns, full-length 16S rRNA gene sequencing, and DNA-DNA hybridization studies (21). These species included C. sakazakii, C. malonaticus, C. turicensis, C. muytjensii, C. dublinensis, and C. genomospecies 1. A new species (C. condimenti) was subsequently identified and in addition $C$. universalis now replaces the original $C$. genomospecies 1 (31). Interestingly, it was proposed that three Enterobacter species, namely E. pulveris, E. helveticus, and E. turicensis, should be included in the genus Cronobacter, being designated as C. pulveris, C. helveticus, and C. zurichensis, respectively (32). This reclassification was based on a multi-locus sequence analysis (MLSA) scheme, using the concatenated nucleotide sequences of $g y r B, r p o B$, inf $B$, and atpD genes to generate a phylogenetic tree, without any further phenotypic characterizations (32). All three species were originally isolated and characterized as Enterobacter species $(33,34)$ but excluded from the Cronobacter species classification due to their obvious phenotypic characteristics (35). More recently, the whole genome sequence (WGS) of these three isolates (36-38), along with a detailed re-examination of their taxonomic status, was reported (39). These data confirmed their exclusion from the genus Cronobacter and furthermore provided the evidence necessary to re-classify them as two new bacterial genera, designated as Siccibater and Franconibacter, respectively (39). Nonetheless, these studies demonstrate the considerable diversity with respect to both geno- and phenotypic characteristics among Cronobacter species and its close taxonomic neighbors, as well as the complexity and challenges, now confronting bacterial taxonomists.

PCR assays targeting species-specific SNPs associated with genes including $r p o B(40,41)$ and $c g c A(42)$ have been developed to facilitate the detection of all seven recognized species within the Cronobacter genus. Figure $\mathbf{2}$ showed the applications of these molecular-based protocols for the identification of Cronobacter species using primers targeting the $r p o B$ gene. Interestingly, using this $r p o B$ protocol, C. malonaticus and C. sakazakii could not be differentiated and required a second PCR reaction to accurately identify each of these species. A multiplex PCR assay targeting the $c g c A$ gene was developed to differentiate species within the genus Cronobacter and this protocol was found to be $100 \%$ specific and sensitive (42). Its advantage over the $r p o B$ method is the ability to directly identity C. sakazakii and C. malonaticus in a single reaction. However, the recently described $C$. condimenti cannot be identified using the $\operatorname{cgc} A$ method (42).

Other biomarkers, in particular virulence genes, also have potential to be used as targets for species identification. Yan et al. (43) designed a PCR and array-based biomarker verification strategy for the detection and identification of Cronobacter species. This strategy was being proposed to facilitate the elucidation of virulence genes, which may be helpful as biomarkers for differentiating Cronobacter species from other food-borne pathogens. However, these putative markers are yet to be validated before their adoption.

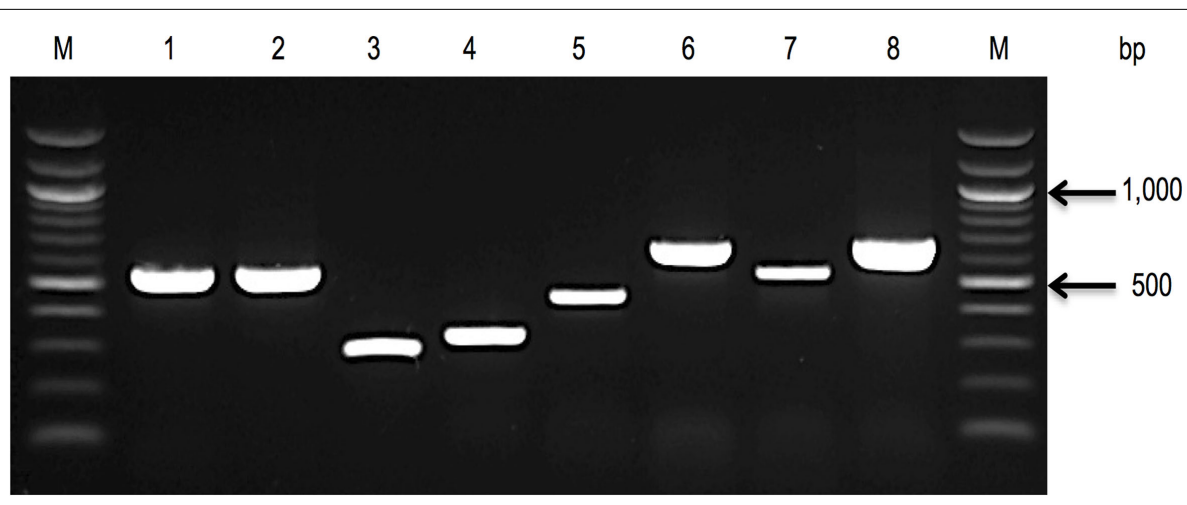

FIGURE 2 | A 1.0\% agarose gel, showing rpoB amplicons, used to identify seven species of the genus $(40,41)$. Lane 1 , C. sakazakii ATCC ${ }^{\circledR}$ BAA-894; Lane 2, C. malonaticus E615 (PCR amplification using rpoB C. sakazakii primer pair); Lane 3, C. malonaticus E615 (a second PCR amplification using rpoB C. malonaticus primer pair); Lane 4, C. muytjensii ATCC $^{\circledR}$ 51329; Lane 5, C. dublinensis E187; Lane 6, C. turicensis E694; Lane 7, C. universalis E680; Lane 8, C. condimenti 1330; and Lane M, 100 bp DNA ladder. 


\section{Serotype Identification}

The O-antigen is a component of the lipopolysaccharide (LPS) structure located on the outer surface of gram-negative bacteria, and is responsible for serological diversity. A molecularbased strategy to identify O-serotype associated with Cronobacter species was described previously (44-48). Mullane et al. (44) initially developed a molecular serotyping method, which included a long-range PCR amplification of the $r f b$-encoding locus (in Gramnegative enteric bacteria located between galF and gnd genes), followed by restriction fragment length polymorphism (RFLP) analysis using $\mathrm{MboII}$. These digests were separated on a conventional agarose gel and visualized under UV light. A tiff image was generated and imported into BioNumerics (Applied Maths, SintMartens-Latem, Belgium). Using this approach, a PCR-RFLP profile of each isolate was produced, which can be compared across various isolates. The first two $\mathrm{O}$-antigen molecular serotypes were denoted as O:1 and O:2 within C. sakazakii (44).

Later, another five additional $\mathrm{O}$-antigens were identified in $C$. sakazakii by Sun et al. (46) and these correlated with the previously reported PCR-RFLP profiles. These molecular-characterization schemes were further extended to include other Cronobacter species and define new molecular O-serotype gene clusters (45, 48). To date, 15 Cronobacter serogroups were identified following the comparison of these PCR amplification schemes, which consist of C. sakazakii O:1-O:4 and O:7; C. malonaticus O:1-O:2; C. dublinensis $\mathrm{O}: 1-\mathrm{O}: 2$, C. muytjensii $\mathrm{O}: 1-\mathrm{O}: 2$, C. universalis $\mathrm{O}: 1$, as well as $C$. turicensis O:1-O:3 (Figure 1). Interestingly, some of the $\mathrm{O}$-serotype gene clusters are shared among various species, such as C. sakazakii O:3 and C. muytjensii O:1, as well as C. malonaticus O:1 and C. turicensis O:1 (49).

\section{Sub-Typing Methods}

Molecular sub-typing has long been regarded as a useful approach that can be applied to elucidate the nature of those bacteria colonizing a particular ecological niche. A number of strategies has been applied for the sub-tying of Cronobacter species, which include pulsed-field gel electrophoresis (PFGE), multilocus sequence typing (MLST), multi-locus variable number tandem-repeat analysis (MLVA), multi-locus sequence analysis (MLSA), as well as matrix-assisted laser desorption ionizationtime of flight mass spectrometry (MALDI-TOP MS) (50). PFGE, and MLST approaches are those most widely in use currently.

\section{Pulsed-Field Gel Electrophoresis}

Nazarowec-White and Farber (51) first applied PFGE to characterize and sub-type Cronobacter species. Mullane et al. (8) characterized and tracked Cronobacter species in a PIF processing facility using PFGE. The study provided a basis for the development of efficient intervention measures contributing to the reduction of Cronobacter in the PIF manufacturing environment. Since then, PFGE approaches have been widely used to track the movement of Cronobacter species in infant foods, soft cheese, various categories of ready-to-eat foods, farming and domestic environments, food producing animals, dried milk, and related products (4, 5262). Meanwhile, a standardized PFGE protocol for sub-typing Cronobacter has been developed and validated by PulseNet, a network of national and regional laboratory sites dedicated to tracking food-borne infections (63). Figure 3 shows an agarose gel with Cronobacter isolates of diverse pulsotypes, cultured from such environments.

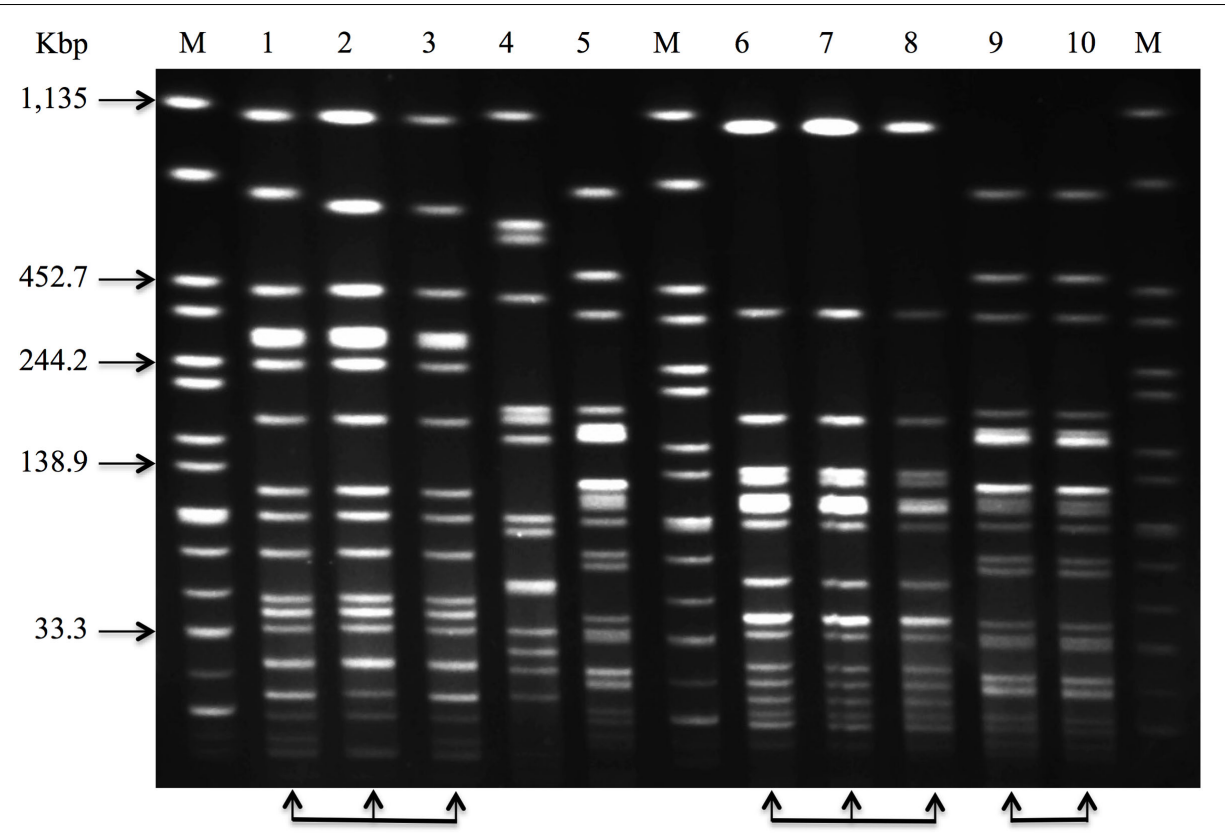

FIGURE 3 | Pulsed-field gel electrophoresis (PFGE) profiles that can be used to characterize and track Cronobacter species in a PIF processing facility. Lane 1-10, sample 1-10, and Lane M, Salmonella Braenderup H9812, molecular marker, genomic DNA digested with Xbal. The arrow-heads at the foot of the image, including lane 1 through 3, lane 6 through 8, lane 9 and 10, show that these isolates have the same PFGE profile and would be considered indistinguishable. 


\section{Multi-Locus Sequence Typing}

A MLST scheme was originally developed by Baldwin et al. (64) to discriminate between C. sakazakii and C. malonaticus. This MLST strategy included seven housekeeping genes: atpD, fusA, $g \ln S, g l t B$, gyrB, infB, pps (3,036 bp concatenated length) that could be used for phylogenetic analysis and comparative genomics (65). Joseph and Forsythe (66) reported the identification of a highly stable sequence type (denoted as ST4) within C. sakazakii and which was responsible for a large proportion of the documented severe neonatal infections, including neonatal meningitis. A database containing defined sequence types (ST) covering all Cronobacter species is currently maintained at the University of Oxford. This database and the associated MLST protocols can be accessed at www.pubMLST.org/cronobacter. Figure 4 described the application of MLST, which includes an initial genomic DNA extraction, PCR amplification of target genes, DNA purification of amplified fragments, Sanger sequencing, alignments to the MLST Cronobacter database, and finally MLST data outputs. This scheme has already been applied in epidemiologic investigations, screening for Cronobacter species in both commercial infant formula products and in hospital or industrial environments $(60,62,67,68)$. However, Pan et al. (62) reported that PFGE demonstrated a superior typing capability when compared with MLST and thereafter suggested a combined approach for the sub-typing of Cronobacter species from food and its related environments.

Additionally, combined with next generation sequencing (NGS), the Cronobacter PubMLST genome and sequence definition database ${ }^{3}$ was established, which covered over 1,000 isolates linked to neonatal meningitis and adult infections (69). These authors identified C. sakazakii clonal complex 4 (CC4) as principally associated with neonatal meningitis. This clonal lineage was confirmed using ribosomal-MLST and whole genome-MLST analysis.

${ }^{3}$ http://www.pubMLST.org/cronobacter

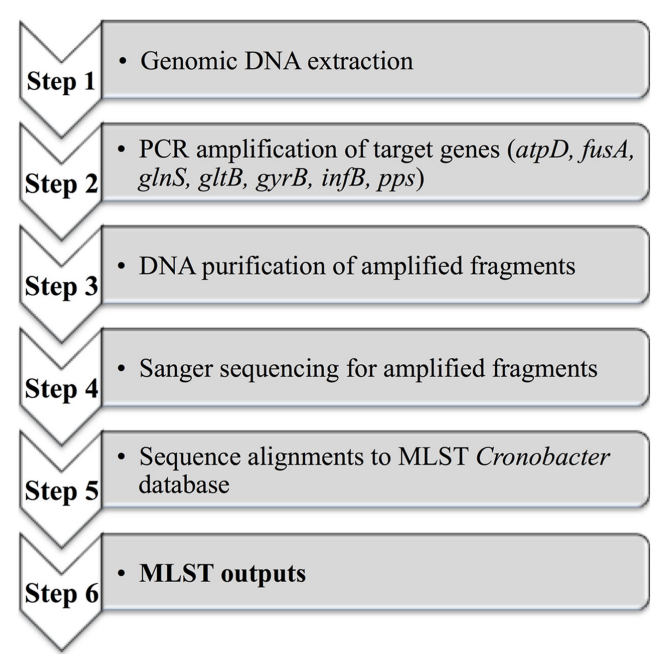

FIGURE 4 | A diagram outlining the MLST scheme from genomic DNA to the MLST outputs.

\section{Sequencing the Genome of Cronobacter species}

Genome sequencing efforts can be expected to facilitate the correct identification of a bacterial species; it can also provide detailed information regarding the unique geno- and phenotypic features. Moreover, these approaches can be used for comparative purposes in order to rapidly and simultaneously investigate the presence/absence of all annotated genes or coding sequences (CDS), and/or nucleotide polymorphisms that may contribute to a specific morphology or physiology.

\section{Whole Genome Sequencing}

Thirty-five Cronobacter genome sequences are currently available at the National Centre for Biotechnology Information (NCBI) as described in Table S1 in Supplementary Material. Only five Cronobacter genomes have been completed or closed, including the genomes of C. sakazakii ATCC ${ }^{\circledR}$ BAA-894, ES15, and SP291, C. turicensis z3032 (LMG 23827), as well as C. malonaticus CMCC 45402 (70-74).

Cronobacter sakazakii ATCC ${ }^{\circledR}$ BAA-894 was the first sequenced isolate (70), which was originally cultured from PIF and epidemiologically linked with an outbreak in a neonatal intensive care unit $(75,76)$. The genome sequence revealed a single chromosome of 4.4 Mbp along with two plasmids, denoted as pESA2 (31 kbp) and pESA3 $(131 \mathrm{kbp})$. The isolate was compared with representatives of five other species using DNA microarray in an effort to further investigate the core genome of Cronobacter along with virulence factors. Among 4,392 annotated genes, some $43 \%$ of the genes were shared across five species, while $55 \%$ of the genes were unique to C. sakazakii. A copper and silver resistance system, which is known to be linked to invasion of the blood-brain barrier by neonatal meningitis causing strains of E. coli (77), was identified in isolates associated with neonatal infections (including $C$. sakazakii, C. malonaticus, and C. turicensis). In particular, genes encoding multidrug efflux pumps and adhesins were found to be unique to C. sakazakii ATCC ${ }^{\circledR}$ BAA-894 (70).

More recently, the complete genome of C. sakazakii SP291 was reported $(73,78)$. This isolate was cultured from a PIF production environment and it represented a cluster of isolates, which were found to be persistent in the PIF production site for at least a period of 2 years. The genome of C. sakazakii SP291 included a $4.3 \mathrm{Mbp}$ chromosome and three plasmids, denoted as pSP291 (118 kbp), pSP291-2 (52 kbp), and pSP291-3 (4 kbp). Compared with C. sakazakii ATCC ${ }^{\circledR}$ BAA-894, C. sakazakii SP291 exhibited a markedly better series of stress response mechanisms (73). Given the fact that C. sakazakii SP291 adapted to the stressful PIF production environment, the osmoprotectant ABC transporters, including YehZYXW, ProP, ProU, and OpuCABCD, can be expected to play an important role in supporting its survival (73), a feature that has been functionally confirmed in other microorganisms (79-82). Furthermore, a greater ability to survive in a broader range of heavy metals was also noted for C. sakazakii SP291, which may be accounted for by its frequent exposure to quaternary ammonium-containing disinfectants (73).

Cronobacter sakazakii ES15 was cultured from ground whole grains, and subsequently sequenced (72). In this case the genome 
consisted of a single chromosome of $4.3 \mathrm{Mbp}$ devoid of any plasmids. Interestingly, a relatively high number of $\mathrm{ABC}$ transport systems and phosphotransferase systems (PTS) were identified in this genome, which may possibly suggest the existence of efficient nutrient uptake systems. In additional, OmpA reported to be involved in the basolateral invasion of the brain by C. sakazakii (83) was also identified.

This isolate C. turicensis z3032, linked with the deaths of two newborn infants in Switzerland in 2005, was subsequently cultured from the blood of one child with meningitis. The genome of this isolate was investigated in an effort to further determine those virulence factors and mechanisms associated with the pathogenicity of these isolates (71). The genome was found to be $4.4 \mathrm{Mbp}$ in size and contained three plasmids of sizes $138 \mathrm{kbp}$ (pCTU1), $22 \mathrm{kbp}$ (pCTU2), and $54 \mathrm{kbp}$ (pCTU3). In all, 4,455 CDS were annotated, with $5 \%$ of them being virulence- and disease-related (71).

The latest WGS to be published was that of C. sakazakii CMCC 45402 (74), which was believed to be C. malonaticus based on the neighbor-joint likelihood phylogeny (13). The $r p o B$ gene of C. malonaticus matched the CMCC 45402 draft genome completely, and which suggested that it was originally mis-identified and is in fact a $C$. malonaticus isolate. This genome included a $4.4 \mathrm{Mbp}$ chromosome with two plasmids of $127 \mathrm{kbp}$ (denoted as $\mathrm{p} 1$ ) and $56 \mathrm{kbp}$ (denoted as p2) in length. The isolate was cultured from a milk sample in China. Genes involved in pathways, such as microbial metabolism in diverse environments, purine metabolism, and $\mathrm{ABC}$ transporter pathways were identified (74).

Grim et al. (84) reported on a comparative genomic analysis of six species of Cronobacter in an attempt to understand the evolution of these bacteria and the genetic contents of each species. A total of 3,160 CDS comprised the core genome of the Cronobacter species (84), which was considerably more than the original 1,899 genes identified using DNA microarray across five species (70). Eighty-four dispensable genomic regions (defined as containing genes present in two or more strains) were also determined. According to Medini et al. (85), the pan genome consists of the sum of the core genome, which includes all genes responsible for the basic aspects of the biology of a species and its major phenotypic traits, as well as dispensable genomes, which contributes to the species diversity and may encode supplementary biochemical pathways and functions that are not essential for bacterial growth but confer selective advantages, such as adaption to different niches, antibiotic resistance, or colonization of a new host. Most notably, several type VI secretion system gene clusters, transposons that carried tellurium, copper and/or silver resistance genes, along with a novel integrative conjugative element (ICE), were identified (84). Furthermore, Cronobacter appeared to have diverged into two clusters, one consisting of C. dublinensis and C. muytjensii (Cdub-Cmuy) and the other comprised of C. sakazakii, C. malonaticus, C. universalis, and $C$. turicensis (Csak-Cmal-Cuni-Ctur). The Cdub-Cmuy clade contained several accessory genomic regions important for survival in a plant-associated environmental niche, while the Csak-CmalCuni-Ctur clade genomes harbored numerous virulence-related genetic traits (84).

\section{Plasmid Sequencing}

Numerous plasmids have been identified in the five completed genomes of Cronobacter, including pESA2 and pESA3 in C. sakazakii ATCC ${ }^{\circledR}$ BAA-894, pSP291-1, pSP291-2, and pSP291-3 in C. sakazakii SP291, pCTU1, pCTU2, and pCTU3 in C. turicensis z3032, as well as p1 and p2 in C. malonaticus CMCC 45402. Yan et al. (73) classified these plasmids into two groups initially, based on their similarity following alignments. With further analysis performed more recently to include those new plasmids that were reported, plasmid group 1 now contains of plasmids pESA3 from C. sakazakii ATCC ${ }^{\circledR}$ BAA-894, pSP291-1 from C. sakazakii SP291, p1 from C. malonaticus CMCC 45402, and pCTU1 from C. turicensis z3032. This group carries two arsenical resistance genes and several putative virulence genes, including two genetic loci encoding iron acquisition systems, namely an $\mathrm{ABC}$ transporter gene cluster and an aerobactin or cronobactin siderophore receptor gene cluster identified as eitCBAD and $i u c A B C D /$ iut $A$, respectively (73). The iucABCD/iutA is reported to be the only active siderophore present in Cronobacter $(84,86)$. Additionally plasmid group 2 now includes plasmids pSP291-2 from C. sakazakii SP291, p2 from C. malonaticus CMCC 45402, and pCTU3 from $C$. turicensis z3032. Fifteen heavy metal (copper, cobalt, zinc, cadmium, lead, and mercury) resistance genes, an osmosensitive $\mathrm{K}^{+}$channel histidine kinase gene $k d p D$ and a virulence associated gene vagC were broadly shared among these plasmids (73). Furthermore, the presence of a Cronobacter plasminogen activatorencoding gene ( $c p a)$ [encoded on plasmids pESA3 and pSP291-1], a single RepFIB-like origin of replication gene (repA) [encoded on pESA3 and pCTU1], a type VI secretion system (T6SS) [encoded on pESA3], a filamentous hemagglutinin/adhesin (FHA) gene locus (located on pCTU1), membrane proteins, suppressor of copper-sensitivity ( $s c s A$ and $s c s B$ ) [shared among pESA3, p1, and pSP291-1], seven arsenical resistance genes (shared between p2 and pCTU3) suggested the existence of unique virulence determinants in these species (73). Other plasmids, including pESA2, pSP291-3, and pCTU2 demonstrated no similarity to any of the above groups, as determined following their alignments and analysis (73).

\section{Microarray-Based Technologies and Deep-Level RNA Sequencing}

DNA Microarray has been applied to investigate the genetic diversity of Cronobacter species previously $(70,87)$. Healy et al. (87) initially designed and performed a microarray-based analysis of Cronobacter species using 276 open reading frame selected from C. sakazakii ATCC ${ }^{\circledR}$ BAA-894 to identify species-specific genes that could be evaluated as candidate markers for inclusion in a molecular-based detection protocol. After completing the WGS of C. sakazakii ATCC ${ }^{\circledR}$ BAA-894, Kucerova et al. (70) constructed a 387,000 probe oligonucleotide microarray in an effort to identify the pan-genome of Cronobacter using five of the seven recognized species. More recently, US-FDA developed a custom designed multi-genome DNA microarray platform that contains over 21,402 unique genes (470,844 probes), representing the pan genome of all seven Cronobacter species (88). Early results showed its capacity to distinguish all seven Cronobacter species from one another and from closely related non-Cronobacter species (88). 
High-throughput whole-transcriptome sequencing (RNA-seq) has also been performed to characterize and fingerprint C. sakazakii responses following exposure to two garlic-derived organosulfur compounds, ajoene and diallyl sulfide (89). Interestingly, RNA-seq revealed that bacteria response to the two compounds differ. For example, ajoene caused downregulation of motilityrelated genes, while diallyl sulfide treatment caused an increased expression of cell wall synthesis genes. These findings will aid the development of effective intervention strategies to decrease the risk of Cronobacter contamination in the food production environments and contact surfaces.

\section{Future Directions}

Cronobacter species, like other microorganisms, can adapt to the production environment. Previous studies reported the isolation of Cronobacter from PIF and its production environment, suggesting that this bacterium has the capacity to adapt to, survive,

\section{References}

1. Jason J. Prevention of invasive Cronobacter infections in young infants fed powdered infant formulas. Pediatrics (2012) 130:e1076-84. doi:10.1542/peds. 2011-3855

2. Bowen AB, Braden CR. Invasive Enterobacter sakazakii disease in infants. Emerg Infect Dis (2006) 12:1185-9. doi:10.3201/eid1208.051509

3. Friedemann M. Epidemiology of invasive neonatal Cronobacter (Enterobacter sakazakii) infections. Eur J Clin Microbiol (2009) 28:1297-304. doi:10.1007/ s10096-009-0779-4

4. Baumgartner A, Grand M, Liniger M, Iversen C. Detection and frequency of Cronobacter spp. (Enterobacter sakazakii) in different categories of ready-toeat foods other than infant formula. Int J Food Microbiol (2009) 136:189-92. doi:10.1016/j.ijfoodmicro.2009.04.009

5. Chap J, Jackson P, Siqueira R, Gaspar N, Quintas C, Park J, et al. International survey of Cronobacter sakazakii and other Cronobacter spp. in follow up formulas and infant foods. Int J Food Microbiol (2009) 136:185-8. doi:10.1016/j. ijfoodmicro.2009.08.005

6. Healy B, Cooney S, O'brien S, Iversen C, Whyte P, Nally J, et al. Cronobacter (Enterobacter sakazakii): an opportunistic foodborne pathogen. Foodborne Pathog Dis (2010) 7:339-50. doi:10.1089/fpd.2009.0379

7. Bar-Oz B, Preminger A, Peleg O, Block C, Arad I. Enterobacter sakazakii infection in the newborn. Acta Paediatr (2001) 90:356-8. doi:10.1111/j.1651-2227. 2001.tb00319.x

8. Mullane NR, Whyte P, Wall PG, Quinn T, Fanning S. Application of pulsedfield gel electrophoresis to characterise and trace the prevalence of Enterobacter sakazakii in an infant formula processing facility. Int J Food Microbiol (2007) 116:73-81. doi:10.1016/j.ijfoodmicro.2006.12.036

9. Kandhai, M.C. (2010). Detection, Occurrence, Growth and Inactivation of Cronobacter spp. (Enterobacter sakazakii). Ph.D. thesis. Wageningen: Wageningen University.

10. Kilonzo-Nthenge A, Rotich E, Godwin S, Nahashon S, Chen F. Prevalence and antimicrobial resistance of Cronobacter sakazakii isolated from domestic kitchens in middle Tennessee, United States. J Food Prot (2012) 75:1512-7. doi:10.4315/0362-028X.JFP-11-442

11. Muytjens HL, Roelofs-Willemse H, Jaspar GH. Quality of powdered substitutes for breast milk with regard to members of the family Enterobacteriaceae. J Clin Microbiol (1988) 26:743-6.

12. Chen Y, Song KY, Brown EW, Lampel KA. Development of an improved protocol for the isolation and detection of Enterobacter sakazakii (Cronobacter) from powdered infant formula. J Food Prot (2010) 73:1016-22.

13. Yan, Q.Q. (2014). Survelliance, Survival and Adaptation of Cronobacter species in Low-Moisture Environments. Ph.D. thesis. Dublin: University College Dublin.

14. Hochel I, Škvor J. Chracterisation of antobodies for the immunochemical detection of Enterobacter sakazakii. Czech J Food Sci (2009) 27:S2-66-77. and persist under desiccated environmental conditions $(53,90)$. With the advantages afforded by NGS technology, isolates of interest can now be investigated in considerable detail. Additionally, the stress response factors identified previously in Cronobacter species, such as heat-shock, cold-stresses, survival in dry conditions, water activity $\left(\mathrm{a}_{\mathrm{w}}\right)$, and $\mathrm{pH}$ need to be re-assessed using RNA-seq and other novel approaches that are currently under development. Advances in our understanding of mechanisms involved with Cronobacter survival will be the key to developing better food safety measures to reduce the risk of Cronobacter contamination in PIF and its production environments and to protect neonatal health.

\section{Supplementary Material}

The Supplementary Material for this article can be found online at http://journal.frontiersin.org/article/10.3389/fped.2015.00038

15. Jaradat ZW, Rashdan AM, Ababneh QO, Jaradat SA, Bhunia AK. Characterization of surface proteins of Cronobacter muytjensii using monoclonal antibodies and MALDI-TOF Mass spectrometry. BMC Microbiol (2011) 11:148. doi:10. 1186/1471-2180-11-148

16. Park S, Shukla S, Kim Y, Oh S, Hun Kim S, Kim M. Development of sandwich enzyme-linked immunosorbent assay for the detection of Cronobacter muytjensii (formerly called Enterobacter sakazakii). Microbiol Immunol (2012) 56:472-9. doi:10.1111/j.1348-0421.2012.00466.x

17. Schauer K, Lehner A, Dietrich R, Kleinsteuber I, Canals R, Zurfluh K, et al. A Cronobacter turicensis $\mathrm{O} 1$ antigen-specific monoclonal antibody inhibits bacterial motility and entry into epithelial cells. Infect Immun (2015) 83:867-87. doi:10.1128/IAI.02211-14

18. Xu X, Zhang Y, Shi M, Sheng W, Du XJ, Yuan M, et al. Two novel analytical methods based on polyclonal and monoclonal antobodies for the rapid detection of Cronobacter spp.: development and application in powdered infant formula. LWT Food Sci Technol (2015) 56:335-40. doi:10.1016/j.lwt.2013.11.028

19. Farmer JJ, Asbury MA, Hickman FW, Brenner DJ. Enterobacter sakazakii a new species of Enterobacteriaceae isolate from clinical specime. Int J Syst Evol Microbiol (1980) 30:569-84.

20. Iversen C, Waddington M, On SL, Forsythe S. Identification and phylogeny of Enterobacter sakazakii relative to Enterobacter and Citrobacter species. J Clin Microbiol (2004) 42:5368-70. doi:10.1128/JCM.42.11.5368-5370.2004

21. Iversen C, Lehner A, Mullane N, Bidlas E, Cleenwerck I, Marugg J, et al. The taxonomy of Enterobacter sakazakii: proposal of a new genus Cronobacter gen. nov. and descriptions of Cronobacter sakazakii comb. nov. Cronobacter sakazakii subsp. sakazakii, comb. nov., Cronobacter sakazakii subsp. malonaticus subsp. nov., Cronobacter turicensis sp. nov., Cronobacter muytjensii sp. nov., Cronobacter dublinensis sp. nov. and Cronobacter genomospecies 1. BMC Evol Biol (2007) 7:64. doi:10.1186/1471-2148-7-64

22. Iversen C, Mullane N, Mccardell B, Tall BD, Lehner A, Fanning S, et al. Cronobacter gen. nov., a new genus to accommodate the biogroups of Enterobacter sakazakii, and proposal of Cronobacter sakazakii gen. nov., comb. nov., Cronobacter malonaticus sp. nov., Cronobacter turicensis sp. nov., Cronobacter muytjensii sp. nov., Cronobacter dublinensis sp. nov., Cronobacter genomospecies 1, and of three subspecies, Cronobacter dublinensis subsp. dublinensis subsp. nov., Cronobacter dublinensis subsp. lausannensis subsp. nov. and Cronobacter dublinensis subsp. lactaridi subsp. nov. Int J Syst Evol Microbiol (2008) 58:1442-7. doi:10.1099/ijs.0.65577-0

23. Seo KH, Brackett RE. Rapid, specific detection of Enterobacter sakazakii in infant formula using a real-time PCR assay. J Food Prot (2005) 68:59-63.

24. Malorny B, Wagner M. Detection of Enterobacter sakazakii strains by real-time PCR. J Food Prot (2005) 68:1623-7.

25. Derzelle S, Dilasser F. A robotic DNA purification protocol and real-time PCR for the detection of Enterobacter sakazakii in powdered infant formulae. BMC Microbiol (2006) 6:100. doi:10.1186/1471-2180-6-100 
26. Liu Y, Cai X, Zhang X, Gao Q, Yang X, Zheng Z, et al. Real time PCR using TaqMan and SYBR Green for detection of Enterobacter sakazakii in infant formula. J Microbiol Methods (2006) 65:21-31. doi:10.1016/j.mimet.2005.06.007

27. Kang ES, Nam YS, Hong KW. Rapid detection of Enterobacter sakazakii using TaqMan real-time PCR assay. J Microbiol Biotechnol (2007) 17:516-9.

28. Cai XQ, Yu HQ, Ruan ZX, Yang LL, Bai JS, Qiu DY, et al. Rapid detection and simultaneous genotyping of Cronobacter spp. (formerly Enterobacter sakazakii) in powdered infant formula using real-time PCR and high resolution melting (HRM) analysis. PLoS One (2013) 8:e67082. doi:10.1371/journal.pone. 0067082

29. Zimmermann J, Schmidt H, Loessner MJ, Weiss A. Development of a rapid detection system for opportunistic pathogenic Cronobacter spp. in powdered milk products. Food Microbiol (2014) 42:19-25. doi:10.1016/j.fm. 2014.02.010

30. Fricker-Feer C, Cernela N, Bolzan S, Lehner A, Stephan R. Evaluation of three commercially available real-time PCR based systems for detection of Cronobacter species. Int J Food Microbiol (2011) 146:200-2. doi:10.1016/j.ijfoodmicro. 2011.02.006

31. Joseph S, Cetinkaya E, Drahovska H, Levican A, Figueras MJ, Forsythe SJ. Cronobacter condimenti sp. nov., isolated from spiced meat, and Cronobacter universalis sp. nov., a species designation for Cronobacter sp. genomospecies 1, recovered from a leg infection, water and food ingredients. Int J Syst Evol Microbiol (2012) 62:1277-83. doi:10.1099/ijs.0.032292-0

32. Brady C, Cleenwerck I, Venter S, Coutinho T, De Vos P. Taxonomic evaluation of the genus Enterobacter based on multilocus sequence analysis (MLSA): proposal to reclassify E. nimipressuralis and E. amnigenus into Lelliottia gen. nov. as Lelliottia nimipressuralis comb. nov. and Lelliottia amnigena comb. nov., respectively, E. gergoviae and E. pyrinus into Pluralibacter gen. nov. as Pluralibacter gergoviae comb. nov. and Pluralibacter pyrinus comb. nov., respectively, E. cowanii, E. radicincitans, E. oryzae and E. arachidis into Kosakonia gen. nov. as Kosakonia cowanii comb. nov., Kosakonia radicincitans comb. nov., Kosakonia oryzae comb. nov. and Kosakonia arachidis comb. nov., respectively, and E. turicensis, E. helveticus and E. pulveris into Cronobacter as Cronobacter zurichensis nom. nov., Cronobacter helveticus comb. nov. and Cronobacter pulveris comb. nov., respectively, and emended description of the genera Enterobacter and Cronobacter. Syst Appl Microbiol (2013) 36:309-19. doi:10.1016/j.syapm.2013. 03.005

33. Stephan R, Van Trappen S, Cleenwerck I, Vancanneyt M, De Vos P, Lehner A. Enterobacter turicensis sp. nov. and Enterobacter helveticus sp. nov., isolated from fruit powder. Int J Syst Evol Microbiol (2007) 57:820-6. doi:10.1099/ijs.0. 64650-0

34. Stephan R, Van Trappen S, Cleenwerck I, Iversen C, Joosten H, De Vos P, et al. Enterobacter pulveris sp. nov., isolated from fruit powder, infant formula and an infant formula production environment. Int J Syst Evol Microbiol (2008) 58:237-41. doi:10.1099/ijs.0.65427-0

35. Iversen C, Druggan P, Schumacher S, Lehner A, Feer C, Gschwend K, et al. Development of a novel screening method for the isolation of "Cronobacter" spp. (Enterobacter sakazakii). Appl Environ Microbiol (2008) 74:2550-3. doi:10. 1128/AEM.02801-07

36. Gopinath GR, Grim CJ, Tall BD, Mammel MK, Sathyamoorthy V, Trach LH, et al. Genome sequences of two Enterobacter pulveris strains, 601/05T (LMG 24057T DSM 19144T) and 1160/04 (LMG 24058 DSM 19146), isolated from fruit powder. Genome Announc (2013) 1:e991-913. doi:10.1128/genomeA. 00991- 13

37. Grim CJ, Gopinath GR, Mammel MK, Sathyamoorthy V, Trach LH, Chase HR, et al. Genome sequence of an Enterobacter helveticus strain, 1159/04 (LMG 23733), isolated from fruit powder. Genome Announc (2013) 1:e1038-1013.

38. Stephan R, Grim CJ, Gopinath GR, Mammel MK, Sathyamoorthy V, Trach LH, et al. Genome sequence of Enterobacter turicensis strain 610/05 (LMG 23731), isolated from fruit powder. Genome Announc (2013) 1:e996-913. doi:10.1128/ genomeA.00996-13

39. Stephan R, Grim CJ, Gopinath GR, Mammel MK, Sathyamoorthy V, Trach $\mathrm{LH}$, et al. Re-examination of the taxonomic status of Enterobacter helveticus, Enterobacter pulveris, and Enterobacter turicensis as members of Cronobacter and description of Siccibacter turicensis com. nov., Franconibacter helveticus comb. nov., and Franconibacter pulveris com. nov. Int J Syst Evol Microbiol (2014) 64:3402-10. doi:10.1099/ijs.0.059832-0

40. Stoop B, Lehner A, Iversen C, Fanning S, Stephan R. Development and evaluation of $r p o B$ based PCR systems to differentiate the six proposed species within the genus Cronobacter. Int J Food Microbiol (2009) 136:165-8. doi:10.1016/j. ijfoodmicro.2009.04.023

41. Lehner A, Fricker-Feer C, Stephan R. Identification of the recently described Cronobacter condimenti by a rpoB based PCR system. J Med Microbiol (2012) 61:1034-5. doi:10.1099/jmm.0.042903-0

42. Carter L, Lindsey LA, Grim CJ, Sathyamoorthy V, Jarvis KG, Gopinath G, et al. Multiplex PCR assay targeting a diguanylate cyclase-encoding gene, $\operatorname{cgcA}$, to differentiate species within the genus Cronobacter. Appl Environ Microbiol (2013) 79:734-7. doi:10.1128/AEM.02898-12

43. Yan X, Gurtler J, Fratamico P, Hu J, Gunther NW, Juneja V, et al. Comprehensive approaches to molecular biomarker discovery for detection and identification of Cronobacter spp. (Enterobacter sakazakii) and Salmonella spp. Appl Environ Microbiol (2011) 77:1833-43. doi:10.1128/AEM.02374-10

44. Mullane N, O'gaora P, Nally JE, Iversen C, Whyte P, Wall PG, et al. Molecular analysis of the Enterobacter sakazakii O-antigen gene locus. Appl Environ Microbiol (2008) 74:3783-94. doi:10.1128/AEM.02302-07

45. Jarvis KG, Grim CJ, Franco AA, Gopinath G, Sathyamoorthy V, Hu L, et al. Molecular characterization of Cronobacter lipopolysaccharide $\mathrm{O}$-antigen gene clusters and development of serotype-specific PCR assays. Appl Environ Microbiol (2011) 77:4017-26. doi:10.1128/AEM.00162-11

46. Sun Y, Wang M, Liu H, Wang J, He X, Zeng J, et al. Development of an Oantigen serotyping scheme for Cronobacter sakazakii. Appl Environ Microbiol (2011) 77:2209-14. doi:10.1128/AEM.02229-10

47. Sun Y, Wang M, Wang Q, Cao B, He X, Li K, et al. Genetic analysis of the Cronobacter sakazakii $\mathrm{O} 4$ to $\mathrm{O} 7 \mathrm{O}$-antigen gene clusters and development of a PCR assay for identification of all C. sakazakii O serotypes. Appl Environ Microbiol (2012) 78:3966-74. doi:10.1128/AEM.07825-11

48. Jarvis KG, Yan QQ, Grim CJ, Power KA, Franco AA, Hu L, et al. Identification and characterization of five new molecular serogroups of Cronobacter spp. Foodborne Pathog Dis (2013) 10:343-52. doi:10.1089/fpd.2012.1344

49. Yan Q, Jarvis KG, Chase HR, Hébert K, Trach LH, Lee C, et al. A proposed harmonized LPS molecular-subtyping scheme for Cronobacter species. Food Microbiol (2015) 50:38-44. doi:10.1016/j.fm.2015.03.003

50. Stephan R, Ziegler D, Pfluger V, Vogel G, Lehner A. Rapid genus- and speciesspecific identification of Cronobacter spp. by matrix-assisted laser desorption ionization-time of flight mass spectrometry. JClin Microbiol (2010) 48:2846-51. doi:10.1128/JCM.00156-10

51. Nazarowec-White M, Farber JM. Phenotypic and genotypic typing of food and clinical isolates of Enterobacter sakazakii. J Med Microbiol (1999) 48:559-67. doi:10.1099/00222615-48-6-559

52. El-Sharoud WM, El-Din MZ, Ziada DM, Ahmed SF, Klena JD. Surveillance and genotyping of Enterobacter sakazakii suggest its potential transmission from milk powder into imitation recombined soft cheese. J Appl Microbiol (2008) 105:559-66. doi:10.1111/j.1365-2672.2008.03777.x

53. Mullane N, Healy B, Meade J, Whyte P, Wall PG, Fanning S. Dissemination of Cronobacter spp. (Enterobacter sakazakii) in a powdered milk protein manufacturing facility. Appl Environ Microbiol (2008) 74:5913-7. doi:10.1128/AEM. 00745-08

54. Proudy I, Bouglé D, Coton E, Coton M, Leclercq R, Vergnaud M. Genotypic characterization of Enterobacter sakazakii isolates by PFGE, BOX-PCR and sequencing of the fliC gene. J Appl Microbiol (2008) 104:26-34. doi:10.1111/ j.1365-2672.2007.03526.x

55. El-Sharoud WM, O'brien S, Negredo C, Iversen C, Fanning S, Healy B. Characterization of Cronobacter recovered from dried milk and related products. BMC Microbiol (2009) 9:24. doi:10.1186/1471-2180-9-24

56. Hein I, Gadzov B, Schoder D, Foissy H, Malorny B, Wagner M. Temporal and spatial distribution of Cronobacter isolates in a milk powder processing plant determined by pulsed-field gel electrophoresis. Foodborne Pathog Dis (2009) 6:225-33. doi:10.1089/fpd.2008.0175

57. Molloy C, Cagney C, O’brien S, Iversen C, Fanning S, Duffy G. Surveillance and characterisation by pulsed-field gel electrophoresis of Cronobacter spp. in farming and domestic environments, food production animals and retail foods. Int J Food Microbiol (2009) 136:198-203. doi:10.1016/j.ijfoodmicro.2009.07.007

58. Craven HM, Mcauley CM, Duffy LL, Fegan N. Distribution, prevalence and persistence of Cronobacter (Enterobacter sakazakii) in the nonprocessing and processing environments of five milk powder factories. J Appl Microbiol (2010) 109:1044-52. doi:10.1111/j.1365-2672.2010.04733.x

59. Miled-Bennour R, Ells TC, Pagotto FJ, Farber JM, Kerouanton A, Meheut T, et al. Genotypic and phenotypic characterisation of a collection of Cronobacter 
(Enterobacter sakazakii) isolates. Int J Food Microbiol (2010) 139:116-25. doi:10. 1016/j.ijfoodmicro.2010.01.045

60. Müller A, Stephan R, Fricker-Feer C, Lehner A. Genetic diversity of Cronobacter sakazakii isolates collected from a Swiss infant formula production facility. J Food Prot (2013) 76:883-7. doi:10.4315/0362-028X.JFP-12-521

61. Cui J, Du X, Liu H, Hu G, Lv G, Xu B, et al. The genotypic characterization of Cronobacter spp. isolated in China. PLoS One (2014) 9:e102179. doi:10.1371/ journal.pone.0102179

62. Pan Z, Cui J, Lyu G, Du X, Qin L, Guo Y, et al. Isolation and molecular typing of Cronobacter spp. in commercial powdered infant formula and follow-up formula. Foodborne Pathog Dis (2014) 11:456-61. doi:10.1089/fpd.2013.1691

63. Brengi SP, O’brien SB, Pichel M, Iversen C, Arduino M, Binsztein N, et al. Development and validation of a PulseNet standardized protocol for subtyping isolates of Cronobacter species. Foodborne Pathog Dis (2012) 9:861-7. doi:10. 1089/fpd.2012.1161

64. Baldwin A, Loughlin M, Caubilla-Barron J, Kucerova E, Manning G, Dowson C, et al. Multilocus sequence typing of Cronobacter sakazakii and Cronobacter malonaticus reveals stable clonal structures with clinical significance which do not correlate with biotypes. BMC Microbiol (2009) 9:223. doi:10.1186/ 1471-2180-9-223

65. Kucerova E, Joseph S, Forsythe S. The Cronobacter genus: ubiquity and diversity. Qual Assur Saf Crop Foods (2011) 3:104-22. doi:10.1111/j.1757-837X.2011. 00104.x

66. Joseph S, Forsythe SJ. Predominance of Cronobacter sakazakii sequence type 4 in neonatal infections. Emerg Infect Dis (2011) 17:1713-5. doi:10.3201/eid1709. 110260

67. Siqueira Santos RF, Da Silva N, Amstalden Junqueira VC, Kajsik M, Forsythe S, Pereira JL. Screening for Cronobacter species in powdered and reconstituted infant formulas and from equipment used in formula preparation in maternity hospitals. Ann Nutr Metab (2013) 63:62-8. doi:10.1159/000353137

68. Gicova A, Orieskova M, Oslanecova L, Drahovska H, Kaclikova E. Identification and characterization of Cronobacter strains isolated from powdered infant foods. Lett Appl Microbiol (2014) 58:242-7. doi:10.1111/lam.12179

69. Forsythe SJ, Dickins B, Jolley KA. Cronobacter, the emergent bacterial pathogen Enterobacter sakazakii comes of age; MLST and whole genome sequence analysis. BMC Genomics (2014) 15:1121. doi:10.1186/1471-2164-15-1121

70. Kucerova E, Clifton SW, Xia XQ, Long F, Porwollik S, Fulton L, et al. Genome sequence of Cronobacter sakazakii BAA-894 and comparative genomic hybridization analysis with other Cronobacter species. PLoS One (2010) 5:e9556. doi:10.1371/journal.pone.0009556

71. Stephan R, Lehner A, Tischler P, Rattei T. Complete genome sequence of Cronobacter turicensis LMG 23827, a food-borne pathogen causing deaths in neonates. J Bacteriol (2011) 193:309-10. doi:10.1128/JB.01162-10

72. Shin H, Lee JH, Choi Y, Ryu S. Complete genome sequence of the opportunistic food-borne pathogen Cronobacter sakazakii ES15. J Bacteriol (2012) 194:4438-9. doi:10.1128/JB.00841-12

73. Yan QQ, Power KA, Cooney S, Fox E, Gopinath GR, Grim CJ, et al. Complete genome sequence and phenotype microarray analysis of Cronobacter sakazakii SP291: a persistent isolate cultured from a powdered infant formula production facility. Front Microbiol (2013) 4:256. doi:10.3389/fmicb.2013.00256

74. Zhao ZJ, Wang L, Wang B, Liang HY, Ye Q, Zeng M. Complete genome sequence of Cronobacter sakazakii strain CMCC 45402. Genome Announc (2014) 2:e1139-1113. doi:10.1128/genomeA.01139-13

75. CDC. Enterobacter sakazakii infections associated with the use of powdered infant formula - Tennessee, 2001. MMWR Morb Mortal Wkly Rep (2002) 51:297-300.

76. Himelright I, Harris E, Lorch V, Anderson M, Jones T, Craig A, et al. Enterobacter sakazakii infections associated with the use of powdered infant formula Tennessee, 2001. MMWR Morb Mortal Wkly Rep (2002) 51:298-300.

77. Franke S, Grass G, Rensing C, Nies DH. Molecular analysis of the coppertransporting efflux system CusCFBA of Escherichia coli. J Bacteriol (2003) 185:3804-12. doi:10.1128/JB.185.13.3804-3812.2003
78. Power KA, Yan QQ, Fox EM, Cooney S, Fanning S. Genome sequence of Cronobacter sakazakii SP291, a persistent thermotolerant isolate derived from a factory producing powdered infant formula. Genome Announc (2013) 1:e0008213. doi:10.1128/genomeA.00082-13

79. Cairney J, Booth IR, Higgins CF. Osmoregulation of gene expression in Salmonella typhimurium: proU encodes an osmotically induced betaine transport system. J Bacteriol (1985) 164:1224-32.

80. Checroun C, Gutierrez C. Sigma(s)-dependent regulation of yehZYXW, which encodes a putative osmoprotectant ABC transporter of Escherichia coli. FEMS Microbiol Lett (2004) 236:221-6. doi:10.1016/j.femsle.2004.05.046

81. Frossard SM, Khan AA, Warrick EC, Gately JM, Hanson AD, Oldham ML, et al. Identification of a third osmoprotectant transport system, the osmU system, in Salmonella enterica. J Bacteriol (2012) 194:3861-71. doi:10.1128/JB. 00495-12

82. Finn S, Handler K, Condell O, Colgan A, Cooney S, Hinton J, et al. ProP is required for the survival of Salmonella typhimurium desiccated on stainless steel. Appl Environ Microbiol (2013) 79:4376-84. doi:10.1128/AEM. 00515-13

83. Kim K, Kim KP, Choi J, Lim JA, Lee J, Hwang S, et al. Outer membrane proteins $\mathrm{A}(\mathrm{OmpA})$ and $\mathrm{X}(\mathrm{OmpX})$ are essential for basolateral invasion of Cronobacter sakazakii. Appl Environ Microbiol (2010) 76:5188-98. doi:10.1128/ AEM.02498-09

84. Grim CJ, Kotewicz ML, Power K, Pagotto F, Gopinath G, Mammel MK, et al. Pan genome analysis of the emerging foodborne pathogen Cronobacter spp. suggests a species-level bidirectional divergence driven by niche adaption. BMC Genomics (2013) 14:366. doi:10.1186/1471-2164-14-366

85. Medini D, Donati C, Tettelin H, Masignani V, Rappuoli R. The microbial pan-genome. Curr Opin Genet Dev (2005) 15:589-94. doi:10.1016/j.gde.2005. 09.006

86. Franco AA, Hu L, Grim CJ, Gopinath G, Sathyamoorthy V, Jarvis KG, et al. Characterization of putative virulence genes on the related RepFIB plasmids harbored by Cronobacter spp. Appl Environ Microbiol (2011) 77:3255-67. doi:10.1128/AEM.03023-10

87. Healy B, Huynh S, Mullane N, O’brien S, Iversen C, Lehner A, et al. Microarraybased comparative genomic indexing of the Cronobacter genus (Enterobacter sakazakii). Int J Food Microbiol (2009) 136:159-64. doi:10.1016/j.ijfoodmicro. 2009.07.008

88. Tall BD, Gangiredla J, Gopinathrao G, Yan Q, Chase HR, Lee B, et al. Development of a custom-designed, pan genomic DNA microarray to characterize strain-level diversity among Cronobacter spp. Front Pediatr (2015) 3:36. doi:10. 3389/fped.2015.00036

89. Feng S, Eucker TP, Holly MK, Konkel ME, Lu X, Wang S. Investigating the responses of Cronobacter sakazakii to garlic-drived organosulfur compounds: a systematic study of pathogenic-bacterium injury by use of high-throughput whole-transcriptome sequencing and confocal micro-raman spectroscopy. Appl Environ Microbiol (2014) 80:959-71. doi:10.1128/AEM. 03460- 13

90. Drudy D, O'rourke M, Murphy M, Mullane NR, O'mahony R, Kelly L, et al. Characterization of a collection of Enterobacter sakazakii isolates from environmental and food sources. Int J Food Microbiol (2006) 110:127-34. doi:10.1016/ j.ijfoodmicro.2006.02.008

Conflict of Interest Statement: The authors declare that the research was conducted in the absence of any commercial or financial relationships that could be construed as a potential conflict of interest.

Copyright (C) 2015 Yan and Fanning. This is an open-access article distributed under the terms of the Creative Commons Attribution License (CC BY). The use, distribution or reproduction in other forums is permitted, provided the original author(s) or licensor are credited and that the original publication in this journal is cited, in accordance with accepted academic practice. No use, distribution or reproduction is permitted which does not comply with these terms. 